EXTENDED REPORT

\title{
Effects of trypan blue on cell viability and gene expression in human retinal pigment epithelial cells
}

\author{
A K H Kwok, C-K Yeung, T Y Y Lai, K-P Chan, C P Pang
}

Br J Ophthalmol 2004;88:1590-1594. doi: 10.1136/bjo.2004.044537

See end of article for authors' affiliations

......................

Correspondence to: Dr Alvin K H Kwok, Department of

Ophthalmology, Hong

Kong Sanatorium and

Hospital, 2 Village Road,

Happy Valley, Hong Kong;

alvinkwok@hksh.com

Accepted for publication 17 May 2004
Aim: To evaluate the effects of trypan blue on cell viability and gene expression in human retinal pigment epithelial (RPE) cells.

Methods: Three concentrations $(0.06 \mathrm{mg} / \mathrm{ml}, 0.6 \mathrm{mg} / \mathrm{ml}$, and $4 \mathrm{mg} / \mathrm{ml})$ of trypan blue were applied to human ARPE 19 cells for 1 minute. Cell viability was measured using the 3-(4,5-dimethylthiazol-2-yl)-2,5diphenyltetrazolium bromide (MTT) assay. RPE cells were sampled daily for 6 consecutive days to assess the effects of trypan blue on cell viability. The effects of trypan blue on the expression of apoptosis related and cell cycle arrest gene expressions including c-fos, c-jun, p53, and p21 were performed using reverse transcription-polymerase chain reaction and immunostaining.

Results: The MTT assay showed a concentration dependent suppression effect of trypan blue on cell viability, with higher reduction in the $0.6 \mathrm{mg} / \mathrm{ml}$ and $4 \mathrm{mg} / \mathrm{ml}$ trypan blue treated groups. No significant change in the expression of c-fos and c-jun was found with all three concentrations of trypan blue. An increase in p53 expression was found in the $4 \mathrm{mg} / \mathrm{ml}$ trypan blue treated group at 10-30 minutes after trypan blue application. Immunostaining showed a mild, albeit insignificant, increase of p53 expression in the RPE cells. No significant increase in p21 expression was observed in the $0.06 \mathrm{mg} / \mathrm{ml}$ trypan blue treated group but there were significant increases in $p 21$ expression in both the $0.6 \mathrm{mg} / \mathrm{ml}(p=0.032)$ and the $4 \mathrm{mg} / \mathrm{ml}(\mathrm{p}=0.025)$ treated groups.

Conclusions: Trypan blue may lead to toxicity on cultured RPE cells as indicated by the reduction in cell viability and changes in the expression of apoptosis related and cell cycle arrest genes at higher concentrations. The application of $0.06 \mathrm{mg} / \mathrm{ml}$ trypan blue for 1 minute appeared to have no significant effect on cultured RPE.
$\mathrm{T}$ rypan blue is a vital stain that has been used as an intraoperative stain to facilitate anterior segment surgery, particularly in the staining of the anterior capsule in white mature cataract. ${ }^{1-3}$ Recently, trypan blue has also been shown to be an useful intraoperative agent for improving the visualisation of peripheral epiretinal membrane (ERM) in patients with proliferative vitreoretinopathy, as well as macular ERM and retinal internal limiting membrane (ILM) in cases of macular pucker and idiopathic macular hole..$^{4-9}$ Improved visualisation is particularly important for thin, cellophane type of ERM, since this can enhance complete removal of the ERM to maximise the long term outcome by minimising ERM recurrence.

Previous studies have demonstrated the safety of intravitreal trypan blue in rabbit eyes as well as in retinal pigment epithelium (RPE) cell culture. ${ }^{10}{ }^{11}$ It has been shown that the application of up to $3 \mathrm{mg} / \mathrm{ml}$ trypan blue for 5 minutes appeared to have no toxic effect on cultured RPE cells in terms of cell viability. ${ }^{11}$ However, intravitreal injection of $2 \mathrm{mg} / \mathrm{ml}$ trypan blue was found to cause marked damage to the inferior retina in rabbit eyes after the presence of intravitreal trypan blue for 4 weeks. ${ }^{10}$ This response is concentration dependent as no evidence of retinal toxicity was found in the rabbit eyes at $0.6 \mathrm{mg} / \mathrm{ml}$ trypan blue, but toxicity was found at concentration of $2 \mathrm{mg} / \mathrm{ml}$. However, it remained uncertain whether this concentration dependent toxicity of trypan blue on the cultured RPE cells was present as a previous study showed no evidence of toxicity at concentrations between $0.6 \mathrm{mg} / \mathrm{ml}$ to $3 \mathrm{mg} / \mathrm{ml} .{ }^{11}$ In these previous studies, the expressions of gene and various proteins associated with cell toxicity were not investigated. Moreover, serial measurements were not performed to investigate the time dependent toxicity effect of trypan blue. Investigating the potential retinal toxicity associated with intraocular dye is important as recent study has suggested potential adverse visual outcome in macular hole surgery with indocyanine green assisted ILM removal. ${ }^{12}$ Adequate testing should therefore be performed before the routine use of intraocular dye. ${ }^{13}$

The aim of this study was to investigate the effects of various concentrations of trypan blue on the viability of cultured human RPE cells. In addition to cell viability, the expressions of various apoptosis related and cell cycle related genes were also evaluated in order to provide a more comprehensive profile of the toxicity of trypan blue on cultured human RPE cells.

\section{MATERIALS AND METHODS \\ Cell culture}

Human ARPE19 cells were obtained from the American Type Culture Collection (Manassas, VA, USA) and grown in a $1: 1$ (vol/vol) mixture of Dulbecco's modified Eagle's and Ham's F12 medium (DF, Gibco, Rockville, MA, USA) containing $3 \mathrm{mM}$ L-glutamine (Gibco), 10\% fetal bovine serum (Gibco), and antibiotics (100 units/ml penicillin $G$ and $100 \mathrm{mg} / \mathrm{ml}$ streptomycin sulfate, Gibco). RPE cells within five passages were grown to $70 \%$ confluence before the application of trypan blue dye.

Abbreviations: ERM, epiretinal membrane; GAPDH, glyceraldehyde-3phosphate dehydrogenase; ILM, internal limiting membrane; MTT assay, 3-(4,5-dimethylthiazol-2-yl)-2,5-diphenyltetrazolium bromide assay; PBS, phosphate buffered saline; RPE, retinal pigment epithelium 


\section{Drug treatment}

ARPE19 cell monolayers were washed twice with 0.01M phosphate buffered saline (PBS, Gibco) and placed in three concentrations of trypan blue $(0.06 \mathrm{mg} / \mathrm{ml}, 0.6 \mathrm{mg} / \mathrm{ml}$, and $4 \mathrm{mg} / \mathrm{ml}$ ). The lower two concentrations of $0.06 \mathrm{mg} / \mathrm{ml}$ and $0.6 \mathrm{mg} / \mathrm{ml}$ trypan blue were prepared using the stock trypan blue solution of $4 \mathrm{mg} / \mathrm{ml}$ concentration (T8154, Sigma, St Louis, MO, USA) and diluted using appropriate volume of $0.01 \mathrm{M}$ PBS as the solvent. The osmolarity of PBS, and trypan blue solutions of $0.06 \mathrm{mg} / \mathrm{ml}, 0.6 \mathrm{mg} / \mathrm{ml}$, and $4 \mathrm{mg} / \mathrm{ml}$ concentrations were measured as $280 \mathrm{mOsM}, 282 \mathrm{mOsM}$, $284 \mathrm{mOsM}$, and $296 \mathrm{mOsM}$, respectively using the Wescor 5500 Vapour Pressure Osmometer. Trypan blue solution was given to the cultured cells for 1 minute with a loading area of $200 \mu \mathrm{l} / \mathrm{cm}^{2}$. The control sample did not contain any dye. After washing twice with PBS, the cells were placed in fresh culture medium containing antibiotics (200 units/ml penicillin $\mathrm{G}$ and $200 \mathrm{mg} / \mathrm{ml}$ streptomycin sulfate, Gibco) and incubated at $37^{\circ} \mathrm{C}$ with $5 \% \mathrm{CO}_{2}$ balanced with air.

\section{Cell viability assay}

ARPE19 cells $\left(5 \times 10^{4}\right.$ cells $)$ were seeded onto 24 well plates and treated with trypan blue as described above. A cell viability assay was performed every 24 hours using the 3 (4,5-dimethylthiazol-2-yl)-2,5-diphenyltetrazolium bromide (MTT) assay. The cells were washed with PBS and $0.5 \mathrm{mg} /$ $\mathrm{ml}$ MTT in serum free medium was added to the culture and incubated at $37^{\circ} \mathrm{C}$ for 3 hours. Formazan extraction was performed with isopropanol and the quantity determined colorimetrically by using a spectrophotometer (NanoDrop, Rockland, DE, USA) at $570 \mathrm{~nm}$ with the correction of interference at $690 \mathrm{~nm}$. For each group, four individual samples were collected and measured. The effects of trypan blue on ARPE19 cell viability was determined daily for 6 consecutive days after the initial trypan blue application. The results were expressed as units of absorbance of MTT at $570 \mathrm{~nm}$. As each group originated from a single pool of cells, the changes in absorbance reflect the changes in the total numbers of viable cells of the same population over time and in relation to concentrations of trypan blue used. The difference in absorbance between the control and trypan blue treated groups were analysed to determine the cell viability. The percentage of viability in the presence of trypan blue was calculated by dividing the absorbance reading of cells under different trypan blue concentrations by the absorbance reading of cells under normal growth (assumed 100\% viability on day 0) without trypan blue.

\section{Gene expression, PCR, and immunochemistry}

Samples of ARPE19 cells were collected at 0, 10, 20, 40, 50, 90, and 120 minutes after the application of trypan blue for RNA isolation. Total RNA was extracted using a RNeasy Kit (Qiagen, CA, USA). Cells were put to lysis buffer containing $1 \% \beta$-mecaptoethanol (Sigma, St Louis, MO, USA), and passed through a QIAShredder column (Qiagen) and the total RNA was obtained following the supplier's protocol. Reverse transcription was performed on $500 \mathrm{ng}$ of total RNA using $10 \mathrm{ng} / \mathrm{ml}$ random primers and SuperScript enzyme (Gibco). cDNA corresponding to 5, 10, 15, and $20 \mathrm{ng}$ of total RNA was amplified with primers specific for glyceraldehyde3-phosphate dehydrogenase (GAPDH) for 25 cycles. Linear range of amplification was determined by plotting the amount of cDNA used in PCR against the optical density of products. Standardised cDNAs corresponding to $10 \mathrm{ng}$ of total RNA were amplified using the following primer pairs: GAPDH: up: 5'-gaa ggt gaa ggt cgg agt-3'; down: 5'-gaa gat ggt gat ggg att tc- $3^{\prime}$. c-fos: up: $5^{\prime}$-aga cag acc aac tag aag atg a-3'; down: 5'-agc tct gtg gcc atg ggc ccc-3'. c-jun: up: 5'-gtg acg gac tgt tct atg act g-3'; down: 5' -ggg ggt cgg cgt ggt ggt gat g-3'. p53: up: 5'-ttg ccg tcc caa gca atg gat ga-3'; down: 5'tct ggg aag gga cag aag atg ac- $3^{\prime}$. The amplification products were then separated on $2 \%$ agarose gel, stained with $0.5 \mu \mathrm{g} /$ $\mathrm{ml}$ ethidium bromide and the band intensity was quantified. The optical density of each reaction was normalised against that of GAPDH.

For the immunochemistry, ARPE19 cells were grown on glass surface precoated with $0.1 \%$ bovine serum albumin (Sigma), $10 \mathrm{ng} / \mathrm{ml}$ fibronectin (Gibco), and $10 \mathrm{ng} / \mathrm{ml}$ laminin (Gibco). Cell samples were harvested 24 hours after the application of trypan blue and fixed with $3 \%$ paraformaldehyde pH 7.40 in $20 \mathrm{mM}$ HBSS-HEPES buffer (Sigma). The fixative was then diluted to $0.5 \%$ and fixed for 30 minutes at room temperature. After antigen retrieval using $50 \mathrm{mM}$ $\mathrm{NH}_{4} \mathrm{Cl}$ in PBS for 30 minutes on ice, the samples were blocked with $10 \%$ fetal bovine serum (FBS) in PBS for 20 minutes on ice to remove the non-specificities. The cell samples were then incubated with antibodies against p53 and p21 proteins (Santa Cruz, CA, USA). Staining was detected by immunofluorescence (secondary antibodies from Amersham, UK and nuclear counterstaining with DAPI from Sigma) or avidin-biotin complex method (Vector Lab, CA, USA) and observed under fluorescent and light microscopes (Zeiss, Germany). The number of positively stained cells was counted in a total of five optical fields of $200 \mu \mathrm{m}$ in diameter each. The mean number of positively stained cells was calculated and compared with the control without trypan blue stain.
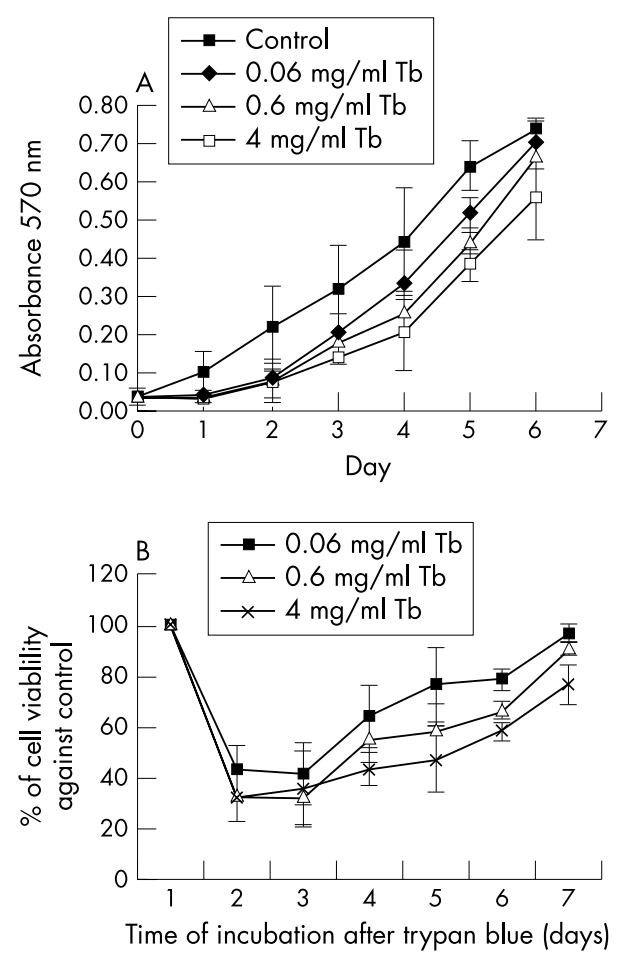

Figure 1 (A) MTT assay showing the proliferation of ARPE19 cells after the application of three concentrations of trypan blue (Tb) compared with control. Greater reduction in cell viability was found with higher concentration of trypan blue. (B) Trypan blue toxicity was expressed as the ratio of viable cells against control. There was a concentration dependent reduction in cell viability caused by trypan blue. Reduction in the percentage of viable cells was most marked in the first 2 days after application of trypan blue. 
A

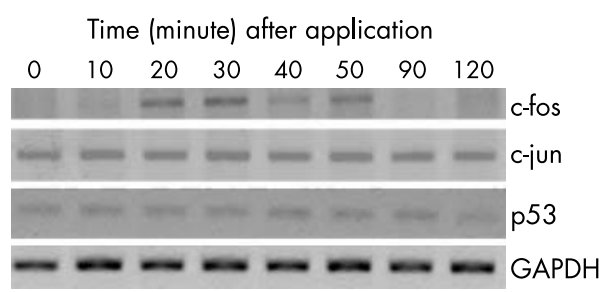

C

Time (minute) after application

$\begin{array}{llllllll}0 & 10 & 20 & 30 & 40 & 50 & 90 & 120\end{array}$

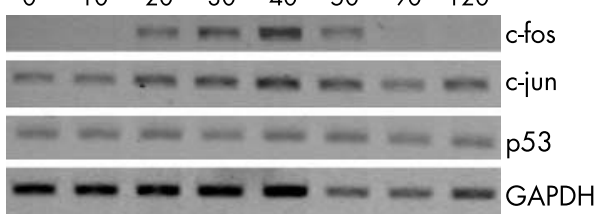

Time (minute) after application

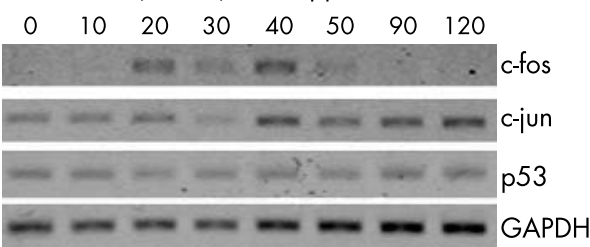

D

- - - - - - GAPDH

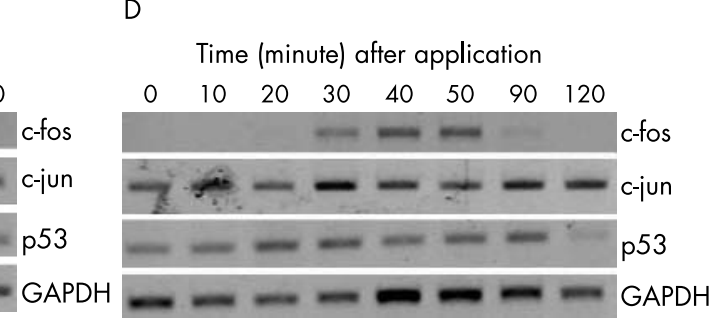

Figure 2 PCR signal intensities of cfos, c-jun, and p53 in ARPE19 cells treated with different concentrations of trypan blue: (A) control; (B) $0.06 \mathrm{mg} /$ $\mathrm{ml} ;(C) 0.6 \mathrm{mg} / \mathrm{ml}$, and (D) $4 \mathrm{mg} / \mathrm{ml}$. Samples were collected at $0,10,20$,

$30,40,50,90$, and 120 minutes. The intensities were compared against that of the GAPDH.

(1)

\section{RESULTS}

\section{Cell viability assay}

The effect of trypan blue on the viability of ARPE19 cells was suppressive and this effect was concentration dependent (fig $1 \mathrm{~A}, \mathrm{~B}$ ). At $0.06 \mathrm{mg} / \mathrm{ml}$ trypan blue, the percentage of viable cells was reduced to $42 \%$ compared with the trypan blue free control group on day 1 and 2. By day 6, the percentage of viable cells recovered to a level similar to the control group. The level of absorbance in the $0.06 \mathrm{mg} / \mathrm{ml}$ trypan blue treated group was not statistically significant when compared with the control group except on day 5 . Higher concentrations of trypan blue at $0.6 \mathrm{mg} / \mathrm{ml}$ and $4 \mathrm{mg} /$ $\mathrm{ml}$ showed a more prominent reduction in the viability of ARPE19. The difference in the level of absorbance compared with the control was statistically significant on day $1-3$ in the $0.6 \mathrm{mg} / \mathrm{ml}$ trypan blue treated group and all time intervals in the $4 \mathrm{mg} / \mathrm{ml}$ trypan blue treated group. The percentage of viable cells was reduced to around 35\% compared with the control group on days 1 and 2 when the cells were being treated with trypan blue at $0.6 \mathrm{mg} / \mathrm{ml}$ and $0.4 \mathrm{mg} / \mathrm{ml}$ (fig $\mathrm{lB}$ ). On day 6, the percentage of viable cells in the $0.6 \mathrm{mg} / \mathrm{ml}$ trypan blue group had recovered to around $90 \%$ of the control level whereas the $4 \mathrm{mg} / \mathrm{ml}$ group had recovered to $76 \%$.

\section{Gene expression}

The expression of apoptosis related gene of the ARPE19 cells in response to trypan blue was investigated. For the control sample and all concentrations of trypan blue, no significant difference in the level of expression for GAPDH in $10 \mathrm{ng}$ of total RNA was detected (fig 2). There were also no significant changes in the RNA expression levels of c-fos and c-jun at various concentrations of trypan blue throughout the 120 minutes of trypan blue application compared with control (fig 3A, B). There was an increase in p53 expression in the $4 \mathrm{mg} / \mathrm{ml}$ trypan blue treated group between 1030 minutes following the initial administration of trypan blue (fig 3C). The p53 expression increased by 1.35 times to that of the control.

Further gene expression studies for $\mathrm{p} 53$ and p2 1 proteins were conducted using immunochemistry. Most of the cells displayed positive staining for $\mathrm{p} 2 \mathrm{l}$ and $\mathrm{p} 53$ proteins after overnight incubation with $10^{-6} \mathrm{M}$ camptothecin, which served as the positive control. For the expression of p53 proteins on immunostaining, a mild increase in the intensity of staining at all the concentrations of trypan blue was observed (fig 4A). However, the change in the level of expression was not statistically significant. For the immunostaining of p2 1 proteins, significant increases in the number of stained cells were found at higher concentrations of $0.6 \mathrm{mg} / \mathrm{ml}$ and $4 \mathrm{mg} / \mathrm{ml}$ trypan blue treated groups compared with the control (Mann-Whitney $U$ test, $p=0.032$ and $p=0.025$ respectively) (fig $4 \mathrm{~B}$ ). There was also a mild increase in the level of p2 1 protein expression for the $0.06 \mathrm{mg} / \mathrm{ml}$ trypan blue treated group but the difference was not statistically significant (Mann-Whitney $\mathrm{U}$ test, $\mathrm{p}=0.157$ ).

\section{DISCUSSION}

In this study, we utilised the MTT assay to determine the effects of various concentrations of trypan blue on the viability of cultured RPE cells. It was found that there was a concentration dependent effect of trypan blue on the cell viability of RPE cells, with higher reductions in the viability of the RPE cells at higher concentrations of trypan blue $(0.6 \mathrm{mg} / \mathrm{ml}$ and $4 \mathrm{mg} / \mathrm{ml}$ ). The effect of trypan blue on decreased RPE cell viability appeared to be transient and was more marked within the first 2 days after the application of trypan blue at all three concentrations. At 6 days after the application of trypan blue, a significant reduction in cell viability was only limited to the $4 \mathrm{mg} / \mathrm{ml}$ trypan blue treated group and no significant change was observed in the groups treated with lower concentrations $(0.06 \mathrm{mg} / \mathrm{ml}$ and $0.6 \mathrm{mg} / \mathrm{ml})$.

Previous studies have evaluated the toxicity of trypan blue on rabbit retina and on cultured RPE cells. ${ }^{10}{ }^{11}$ Veckeneer et $a l^{10}$ reported the lack of retinal toxicity, both histologically and electrophysiologically, in rabbit eyes 4 weeks after intravitreal injection of $0.6 \mathrm{mg} / \mathrm{ml}$ trypan blue. However, at a higher concentration of $2 \mathrm{mg} / \mathrm{ml}$ trypan blue, light and electron microscopy revealed damaged photoreceptors and marked retinal layer disorganisation in the inferior retina. The finding suggested that a lower concentration of trypan blue should be used in vitreoretinal surgery. In another study on the effects of trypan blue on culture RPE cells, no evidence of increased cell death at concentrations of up to $3 \mathrm{mg} / \mathrm{ml}$ after 5 minutes was found. ${ }^{11}$ This is contrary to our results that with the application of trypan blue for 1 minute, reductions in cell viability of the $0.6 \mathrm{mg} / \mathrm{ml}$ and $4 \mathrm{mg} / \mathrm{ml}$ trypan blue treated groups were observed. One of the reasons is the difference in the concentrations of trypan blue used in the two experiments, as limited toxicity of trypan blue on RPE cell was found at a lower concentration of $0.06 \mathrm{mg} / \mathrm{ml}$. Another reason for the lack of cell toxicity caused by trypan blue in the previous study may be because of the timing of the cell viability measurement. In the study by Stalmans et al cell viability was measured using live/dead fluorescent kit 

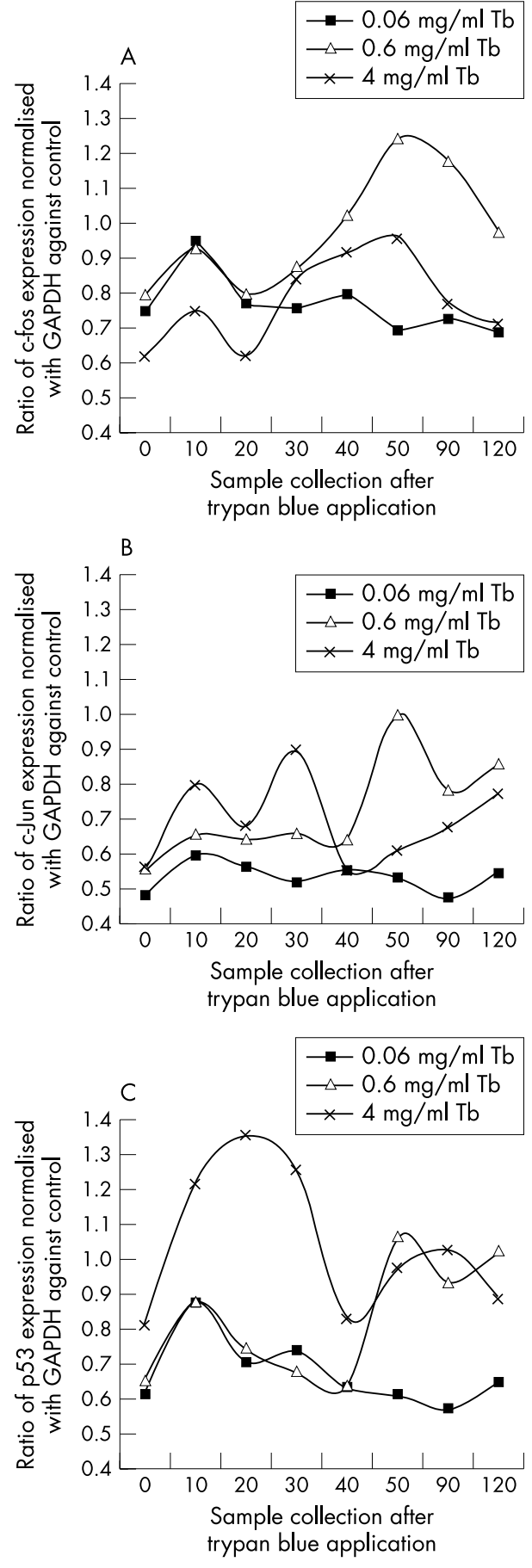

Figure 3 Quantification of PCR signal intensities of (A) c-fos, (B) c-jun, and (C) p53 in ARPE19 after the application of trypan blue (Tb) compared with control. No significant increase in expression of c-fos or c-jun was found. For the $4 \mathrm{mg} / \mathrm{ml}$ trypan blue treated group, there was an increase in the expression of p53 from 10-30 minutes following trypan blue application.

with a confocal microscope after 30 minutes of incubation. ${ }^{11}$ Serial measurements of cell viability in our study allowed the monitoring of cell viability at various time points. This is important since the effect of trypan blue on cell culture is time dependent and the reduction in cell viability caused by trypan blue may not be detected if the samples were measured too early or too late. The short incubation time in previous study, therefore, might not have reflected the true toxicity of trypan blue on the RPE cells. ${ }^{11}$
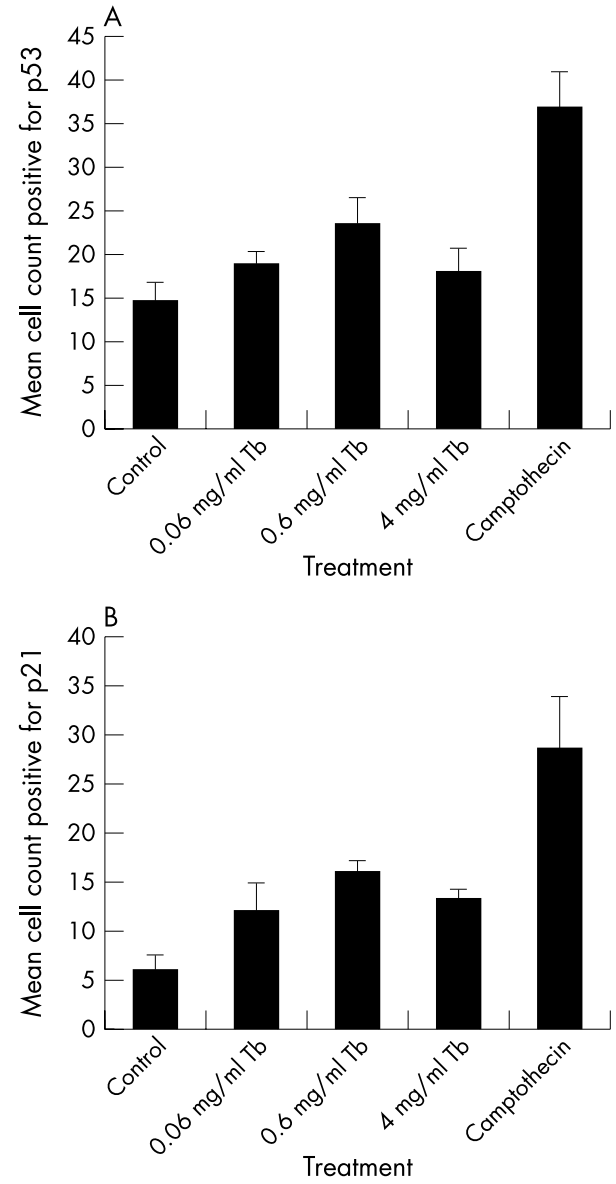

Figure 4 Immunofluorescence of (A) p53 and (B) p21. No significant difference in the number of cells stained positive for p53 was observed for various concentrations of trypan blue. Significant increase in the number of p21 positively stained cells was observed in $0.6 \mathrm{mg} / \mathrm{ml}$ and $4 \mathrm{mg} / \mathrm{ml}$ trypan blue treated groups.

Cellular response to stresses and toxic agents may involve the expressions of genes that have roles in cell regulation and transformation. ${ }^{14}$ Various transcriptions factors are involved in the expression of apoptosis associated genes such as p53, c-fos, and c-jun. ${ }^{15}{ }^{16}$ In this study, PCR and immunostaining were used to evaluate the gene expressions of various apoptosis related and cell cycle related genes. Results from the PCR on the level of expressions for c-fos and c-jun showed no significant change within the first 2 hours after application of the three concentrations of trypan blue. At the highest concentration of $4 \mathrm{mg} / \mathrm{ml}$ of trypan blue, there was an increased expression of p53 at 10-30 minutes after the application of trypan blue compared with control. Immunostaining of p53 of the RPE cells also showed an increased number of positively stained cells at all three concentrations of trypan blue compared with control but the level did not reach statistical significance. For the p2l expression, significant increase in number of cells with p2l expression was found at all three concentrations of trypan blue compared with control. The p21 protein is an inhibitor of cyclin dependent kinases and can arrest cells in the G0-Gl phase. ${ }^{17} 18$ The increase in p21 in ARPE19 cells caused by trypan blue may imply the arrest of cell cycle progression or induction of transient arrest in the Gl phase, making room for DNA repair and therefore the cell growth is retarded. This is supported by the cell viability study using MTT since the reduction of cell viability is most marked in the first 2 days after the application of trypan blue and the reduction of cell viability is less significant on day 6 . 
In summary, a concentration dependent reduction in cultured RPE cell viability may occur after the application of trypan blue. No significant changes in the expressions of cfos and c-jun were observed. However, increased p53 expression was found at the highest concentration of $4 \mathrm{mg} /$ $\mathrm{ml}$ trypan blue treated group. There was also a significant increase in the expression of $\mathrm{p} 21$ protein at all concentrations of trypan blue as demonstrated in the RPE cells using immunofluorescence. Since the commercially available trypan blue for intraocular use contains trypan blue at concentrations of $0.6 \mathrm{mg} / \mathrm{ml}$ or higher, our findings suggest that the concentration to be used clinically may need to be lowered in order to prevent possible toxicity to the RPE or other cells. Moreover, in order to minimise the concentration dependent toxicity associated with trypan blue, partial fluidair exchange performed before injection of trypan blue may be potentially harmful as this may increase the local concentration of the dye. Further in vivo and in vitro studies of intraocular dyes are warranted.

\section{Authors' affiliations}

A K H Kwok, Department of Ophthalmology, Hong Kong Sanatorium and Hospital, Hong Kong, People's Republic of China

A K H Kwok, C-K Yeung, T Y Y Lai, K-P Chan, C P Pang, Department of Ophthalmology and Visual Sciences, The Chinese University of Hong Kong, Hong Kong, People's Republic of China

Financial support: Nil.

Financial interest: Nil.

\section{REFERENCES}

1 Melles GR, de Waard PW, Pameyer JH, et al. Trypan blue capsule staining to visualize the capsulorhexis in cataract surgery. J Cataract Refract Surg 1999;25:7-9.
2 Bhartiya P, Sharma N, Ray M, et al. Trypan blue assisted phacoemulsification in corneal opacities. Br J Ophthalmol 2002;86:857-9.

3 Ermis SS, Ozturk F, Inan UU. Comparing the efficacy and safety of phacoemulsification in white mature and other types of senile cataracts. Br J Ophthalmol 2003;87:1356-9.

4 Feron EJ, Veckeneer M, Parys-Van Ginderdeuren R, et al. Trypan blue staining of epiretinal membranes in proliferative vitreoretinopathy. Arch Ophthalmol 2002;120:141-4.

5 Stalmans P, Feron EJ, Parys-Van Ginderdeuren R, et al. Double vital staining using trypan blue and infracyanine green in macular pucker surgery. Br J Ophthalmol 2003;87:713-16.

6 Kwok AK, Lai TY, Li WW, et al. Trypan blue and indocyanine green assisted epiretinal membrane surgery: clinical and histopathological studies. Eye. advance online publication, 5 March 2004; doi: 10, 1038/sj.eye.6701359..

7 Li K, Wong D, Hiscott P, et al. Trypan blue staining of internal limiting membrane and epiretinal membrane during vitrectomy: visual results and histopathological findings. Br J Ophthalmol 2003;87:216-19.

8 Teba FA, Mohr A, Eckardt C, et al. Trypan blue staining in vitreoretinal surgery. Ophthalmology 2003;1 10:2409-12.

9 Perrier M, Sebag M. Trypan blue-assisted peeling of the internal limiting membrane during macular hole surgery. Am J Ophthalmol 2003;135:903-5.

10 Veckeneer M, van Overdam K, Monzer J, et al. Ocular toxicity study of trypan blue injected into the vitreous cavity of rabbit eyes. Graefes Arch Clin Exp Ophthalmol $2001 ; 239: 698-704$

11 Stalmans P, Van Aken EH, Melles G, et al. Trypan blue not toxic for retinal pigment epithelium in vitro. Am J Ophthalmol 2003;135:234-6.

12 Ando F, Sasano K, Ohba N, et al. Anatomic and visual outcomes after indocyanine green-assisted peeling of retinal internal limiting membrane in idiopathic macular hole surgery. Am J Ophthalmol 2004;137:609-14.

13 Sebag J. Indocyanine green-assisted macular hole surgery: too pioneering? Am J Ophthalmol 2004; 137:744-6.

14 Yonish-Rouach E, Deguin V, Zaitchouk T, et al. Transcriptional activation plays a role in the induction of apoptosis by transiently transfected wild-type p53. Oncogene 1995;11:2197-205.

15 Isoherranen K, Westermarck J, Kahari VM, et al. Differential regulation of AP-1 family members by UV irradiation in vitro and in vivo. Cell Signal 1998;10:191-5.

16 Chao C, Saito S, Kang J, et al. p53 transcriptional activity is essential for p53dependent apoptosis following DNA damage. EMBO J 2000;19:3967-75.

17 Vogelstein B, Lane D, Levine AJ. Surfing the p53 network. Nature 2000:408:307-10

18 Sherr CJ, Roberts JM. CDK inhibitors: positive and negative regulators of G1phase progression. Genes Dev 1999;13:1501-2. 